\title{
Loss of the Toluene-Xylene Catabolic Genes of TOL Plasmid pWWo during Growth of Pseudomonas putida on Benzoate Is Due to a Selective Growth Advantage of 'Cured' Segregants
}

\author{
By PETER A. WILliaMS, * SUSAN D. TAYLOR AND LINDA E. GIBB \\ Department of Biochemistry \& Soil Science, University College of North Wales, Bangor, \\ Gwynedd LL57 2UW, UK
}

(Received 29 October 1987; revised 22 February 1988)

\begin{abstract}
During growth on benzoate-minimal medium Pseudomonas putida $\mathrm{mt}-2(\mathrm{PaW} 1)$ segregates derivative ('cured') strains which have lost the ability to use the pathway encoded by its resident catabolic plasmid pWW0. Experiments with two plasmids identical to pWW0 but each with an insert of Tn401, which confers resistance to carbenicillin, suggested that the 'benzoate curing' occurs far more' frequently by the specific deletion of the $39 \mathrm{kbp}$ region carrying the catabolic genes than by total plasmid loss. This effect was not $\mathrm{pH}$-dependent, and was not produced during growth on other weak organic acids, such as succinate or propionate, or when benzoate was present in the medium with an alternative, preferentially used carbon source such as succinate. Growth on benzoate did not cause loss from strain PaW174 of the plasmid pWW0174 , a derivative of $\mathrm{pWW} 0$ which has deleted the $39 \mathrm{kbp}$ region but carries Tn401. Similarly the naphthalene-catabolic plasmid pWW60-1, of the same incompatibility group as pWW0, was not lost from $\mathrm{PaW} 701$ during growth on benzoate. Competition between wild-type PaW1 and PaW174, which has the 'cured' phenotype, showed that the latter has a distinct growth advantage on benzoate over the wild-type even when initially present as only $1 \%$ of the population: when PaW174 was seeded at lower cell ratios, spontaneously 'cured' derivatives of $\mathrm{PaW} 1$ took over the culture after $60-80$ generations, indicating that they are present in PaW1 cultures at frequencies between $10^{-2}$ and $10^{-3}$. We conclude that the progressive takeover of populations of $\mathrm{PaW} 1$ only occurs when benzoate is present as the sole growth source and that neither benzoate, nor other weak acids, affect plasmid segregation or deletion events: a sufficient explanation is that the 'cured' segregants grow faster than the wild-type using the chromosomally determined $\beta$-ketoadipate pathway.
\end{abstract}

\section{INTRODUCTION}

The observation that Pseudomonas putida mt-2 underwent an irreversible spontaneous phenotypic change which affected its growth on benzoate was first reported by Nakazawa \& Yokota (1973), who noticed faster-growing colonies when the bacteria were spread on to agar plates containing benzoate-yeast extract medium. The phenomenon was explained when it was later shown that $P$. putida $\mathrm{mt}-2$ harbours a plasmid which encodes the genes responsible for the catabolism of benzoate (and $m$ - and $p$-toluates) by the meta cleavage pathway (see Fig. 1) (Williams \& Murray, 1974). Segregants of strain mt-2 (also called PaW1) appeared after growth for $>20$ generations on $5 \mathrm{mM}$-benzoate-minimal medium (BMM): they had irreversibly lost the entire set of catabolic genes encoded by the plasmid (pWW0), rendering them unable to grow on $m$-toluate $\left(\mathrm{Mtol}^{-}\right)$or $p$-toluate (Williams \& Murray, 1974) or on the hydrocarbons toluene and $m$ and $p$-xylenes, which were subsequently shown to be the precursors of benzoate, $m$ - and $p$ -

Abbreviation: BMM, benzoate-minimal medium.

0001-4503 (C) 1988 SGM 
plasmid $\underbrace{\text { COL }}_{\mathbf{R}_{2}} \rightarrow \rightarrow \overbrace{\mathbf{R}_{\mathbf{R}_{2}}}^{\text {Central }}$

2-Hydroxymuconic semialdehyde

Chromosomal

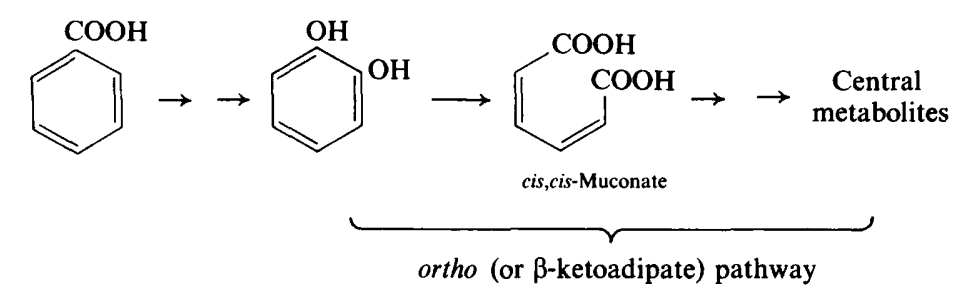

Fig. 1. Pathways for catabolism of aromatic compounds in $P$. putida mt-2 (PaW1) and its derivative strains. The pathway determined by TOL plasmids dissimilates toluene $\left(R_{1}=R_{2}=H\right)$, $m$-xylene $\left(\mathrm{R}_{1}=\mathrm{CH}_{3}, \mathrm{R}_{2}=\mathrm{H}\right)$ and $p$-xylene $\left(\mathrm{R}_{1}=\mathrm{H}, \mathrm{R}_{2}=\mathrm{CH}_{3}\right)$, through benzoate, $m$-toluate and $p$-toluate respectively and then by the meta cleavage pathway to central metabolites. The chromosomally determined pathway will metabolize only benzoate via the ortho or $\beta$-ketoadipate pathway. The plasmid pathway is induced by both the hydrocarbons and the carboxylic acids substrates, and is thus utilized when they are presented as growth substrates. The primary inducer of ortho cleavage is cis,cismuconate, the product of its first enzyme, catechol 1,2-oxygenase. This pathway is therefore only induced when the plasmid pathway is absent, either by loss of the plasmid or by deletion of the catabolic genes from the plasmid, such that some muconate can be formed by the action of the basal uninduced catechol 1,2-oxygenase upon catechol formed from benzoate.

toluates respectively on the plasmid-determined pathway (Worsey \& Williams, 1975). The segregants retained the ability to grow well on benzoate $\left(\mathrm{Ben}^{+}\right)$but they dissimilated it by the alternative, but chromosomally coded, ortho (or $\beta$-ketoadipate) pathway (Nakazawa \& Yokota, 1973; Williams \& Murray, 1974) which is ubiquitous in P. putida strains (Fig.1). Williams \& Murray (1974) proposed that the segregants had spontaneously lost the plasmid and, using the chromosomal route for benzoate catabolism, were able to grow faster than the wild-type, which was thus outcompeted during subsequent culture. Once physical isolation of the large Pseudomonas plasmids was possible, it was shown that the hypothesis was partly correct since some of the so-called 'benzoate-cured' segregants were in fact plasmid-free, but in others the same phenotype was found to be produced by a specific large deletion of $39 \mathrm{kbp}$ from pWW0 (Bayley et al., 1977); this $39 \mathrm{kbp}$ region has been shown to carry all of the catabolic genes for the toluene-xylene pathway (Franklin et al., 1981; Lehrbach \& Timmis, 1983).

The procedure of growing strains on BMM has been used with nearly all Pseudomonas strains which have been isolated with plasmids carrying the same catabolic function as pWW0 (the TOL plasmids) and without exception it has been found that it exerts a strong selective pressure against the wild-type and results in the appearance either of plasmid-free segregants or of mutants, phenotypically distinguishable from the wild-type, with functional lesions in the pathway and deletions in the plasmids (Williams \& Worsey, 1976; Worsey \& Williams, 1977; Kunz \& Chapman, 1981; Pickup \& Williams, 1982; Pickup et al., 1983; Keil \& Williams, 1985). This phenomenon is particularly apparent with certain Pseudomonas strains which carry a subclass of large TOL plasmids ( $\geqslant 250 \mathrm{kbp}$ ), strains MT14, MT15 and MT20. These strains segregate mutants at very high frequency during growth on benzoate (Williams \& Worsey, 1976), producing several classes of phenotypically distinguishable deletion mutants (Worsey \& Williams, 1977; Pickup \& Williams, 1982; Keil \& Williams, 1985) and contain very related plasmids but ones structurally distinct from pWW0 (Keil \& Williams, 1985). 
It has always been assumed in this laboratory that the growth-rate hypothesis was sufficient to explain all these instances. However, the difficulties of accurately measuring small differences in growth rates in batch cultures have made the hypothesis largely untested, except in the case of $P$. putida MT20, where the cured and deletion mutants grow considerably more rapidly than the wild-type (Worsey \& Williams, 1977).

Recently several papers from other laboratories have cast doubts on the hypothesis. Keshavarz et al. (1985) carried out long-term chemostat culture of a TOL-plasmid-containing isolate and suggested that the results could only be explained if benzoate had some effect on the partitioning of the plasmid. Stephens \& Dalton (1987) have interpreted experiments with $P$. putida MT15 as demonstrating that the undissociated acid molecules of benzoate, and other weak organic acids, act to promote plasmid loss and/or deletion. Clarke \& Laverack (1984) also showed that, at much higher concentrations than used in any of the growth experiments, benzoate could cause spontaneous loss, not only of TOL plasmids, but also of naphthalene catabolic plasmids.

In this paper we return to $P$. putida $\mathrm{mt}-2$ (PaW1), host to the archetypal TOL plasmid pWW0, and demonstrate, with the use of genetically marked derivative strains, that 'benzoate curing', involving either plasmid loss or deletion, is entirely consistent with the occurrence of relatively frequent spontaneous events which are then amplified by a faster growth of the segregants on benzoate.

\section{METHODS}

Strains. A list of the strains of $P$. putida $\mathrm{mt}-2$ used in this study is presented in Table 1.

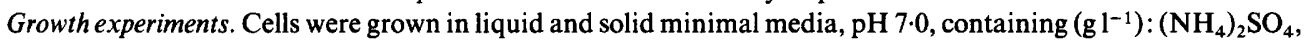
$1 \cdot 0 ; \mathrm{KH}_{2} \mathrm{PO}_{4}, 2 \cdot 5 ; \mathrm{MgSO}_{4} .7 \mathrm{H}_{2} \mathrm{O}, 0 \cdot 1 ; \mathrm{FeSO}_{4}, 5 \times 10^{-3}$; nitrilotriacetic acid, $0 \cdot 25 ; \mathrm{NaOH}, 0 \cdot 55$; and $1 \mathrm{ml} \mathrm{l}^{-1}$ of the stock salts solution of Bauchop \& Elsden (1960). In some experiments the minimal medium was supplemented with $\mathrm{KH}_{2} \mathrm{PO}_{4}$ to a final concentration of $7.5 \mathrm{~g} \mathrm{l}^{-1}$; this was to increase its buffering capacity and thus minimize the effect of any increase of $\mathrm{pH}$ during growth. This medium is referred to as 'high phosphate'. Starting cultures were from single colonies inoculated into nutrient broth and grown overnight at $30^{\circ} \mathrm{C}$ to cell densities of about 4-8 $\times$ $10^{8} \mathrm{ml}^{-1}$. Dilutions of $10^{-5}$ were made in sterile phosphate buffer, $\mathrm{pH} 7.5$, and $0 \cdot 1 \mathrm{ml}$ was inoculated into $5 \mathrm{ml}$ of the selected growth medium which was then incubated at $30^{\circ} \mathrm{C}$ in a rotary shaker until turbid growth was seen: this was normally after $24 \mathrm{~h}$. The cultures, which had cell densities of around $10^{8} \mathrm{ml}^{-1}$, were serially diluted and $0 \cdot 1$ ml volumes of $10^{-4}$ and $10^{-5}$ dilutions were spread on to nutrient agar plates. A $0 \cdot 1 \mathrm{ml}$ volume of the $10^{-5}$ dilution (usually containing about 50-200 cells) was also inoculated into $5 \mathrm{ml}$ of fresh growth medium for the second cycle of growth, and so on. Each cycle was therefore about 22 generations, apart from the first of each series, with its inoculum from a nutrient broth culture, which was probably some 2-3 generations less. It follows from the fact that only of the order of $10^{2}$ cells were transferred from one subculture to the next, that any strain in the population which drops to around $1 \%$ of the total cells stands a strong chance of being totally eliminated from the next subculture. After incubating the agar plates overnight, 88 isolated colonies were selected and transferred to appropriate selection plates in order to test their phenotype. Benzoate and $m$-toluate were incorporated into minimal salts agar at $5 \mathrm{~mm}$ and carbenicillin into Isosensitest agar at $2 \mathrm{mg} \mathrm{ml}^{-1}$. For the early experiments using growth of PaWl (data of Table 2 only), the phenotype of the colonies on the agar plates was examined by spraying

\section{Table 1. Pseudomonas putida strains used}

\begin{tabular}{|c|c|c|c|}
\hline Strain & Plasmid & $\begin{array}{c}\text { Relevant } \\
\text { phenotype* }\end{array}$ & Notes and reference \\
\hline PaWl & pWW0 & $\mathrm{Mtol}^{+} \mathrm{Ben}^{+}$ & P. putida mt-2 wild-type (Williams \& Murray, 1974) \\
\hline $\mathrm{PaW} 8$ & pWW0-8 & $\mathrm{Mtol}^{-} \mathrm{Ben}^{+}$ & $\begin{array}{l}\text { 'Benzoate-cured' segregant of PaW1 (Williams \& Murray, } \\
\text { 1974) }\end{array}$ \\
\hline PaW163 & pWW0-163 & $\mathrm{Mtol}^{+} \mathrm{Ben}^{+} \mathrm{Cb}^{r}$ & Plasmid is pWW0: :Tn401. Gift of J. Shapiro \\
\hline $\mathrm{PaW} 164$ & pWW0-164 & $\mathrm{Mtol}^{+} \mathrm{Ben}^{+} \mathrm{Cb}^{\mathrm{r}}$ & Plasmid is pWW0: :Tn401. Gift of J. Shapiro \\
\hline $\mathrm{PaW} 174$ & pWW0-174 & $\mathrm{Mtol}^{-} \mathrm{Ben}^{+} \mathrm{Cb}^{r}$ & $\begin{array}{l}\text { 'Benzoate-cured' segregant of PaW164 carrying a } \\
\text { pWW0-8::Tn401 plasmid. This paper }\end{array}$ \\
\hline PaW701 & pWW60-1 & $\mathrm{Nah}^{+} \mathrm{Ben}^{+}$ & $\begin{array}{l}\text { Carries IncP9 naphthalene-catabolic plasmid (Cane \& } \\
\text { Williams, 1982) }\end{array}$ \\
\hline
\end{tabular}

* Phenotype designations: $\mathrm{Mtol}^{+}, \mathrm{Ben}^{+}, \mathrm{Nah}^{+}$, abilities to grow on $m$-toluate, benzoate, naphthalene as sole carbon sources; $\mathrm{Cb}^{\mathrm{r}}$, resistance to carbenicillin. 
the plates with $100 \mathrm{~mm}$-catechol; whereas wild-type cells $\left(\mathrm{Mtol}^{+} \mathrm{Ben}^{+}\right)$turn yellow within 1-2 min due to the conversion of the catechol to 2-hydroxymuconic semialdehyde by the plasmid-coded catechol 2,3-oxygenase, the 'cured' strains $\left(\mathrm{Mtol}^{-} \mathrm{Ben}^{+}\right)$stay white.

Competition experiments. These were done as for the growth experiments above except that the two overnight starter cultures, assumed to be roughly of the same cell density, were diluted to different extents and mixed to give expected initial cell ratios (PaW $1: \mathrm{PaW} 174)$ of $1: 1,50: 1$ and $10^{3}: 1$ which were then inoculated into $5 \mathrm{ml}$ of BMM. The actual cell ratios were determined by doing plate counts on the two starter cultures. The mixed cultures were subsequently treated exactly as when growing from a single culture.

Plasmid isolation. Plasmids were isolated and their restriction digestion pattern examined according to Wheatcroft \& Williams (1981).

\section{RESULTS}

\section{Growth of single strains}

In a preliminary experiment we confirmed that $\mathrm{PaW} 1$ segregated mutant strains which had lost the plasmid-coded pathway during growth on $\mathrm{BMM}$ at a range of initial $\mathrm{pH}$ values from $7 \cdot 2$ to 6.4 (Table 2). At all pH values the proportion of $\mathrm{Mtol}^{-}$strains increased through successive growth cycles and there was no apparent relationship with $\mathrm{pH}$ for either the first appearance of segregants or the rate of loss of wild-type. Rather, there was as great a variation between replicates at the same $\mathrm{pH}$ as at different $\mathrm{pH}$ values, suggesting that the onset of wild-type loss is dependent upon random or stochastic events. The use of high-phosphate mineral salts medium also had no significant effect. In these experiments we checked the $\mathrm{pH}$ at the end of each growth cycle and in all 12 determinations it was within \pm 0.2 of the initial $\mathrm{pH}$, showing that the effect could not be attributed to $\mathrm{pH}$ changes in the medium.

PaW174 carries a plasmid, pWW0-174, derived from pWW0. All the catabolic genes have been deleted between the $1.4 \mathrm{kbp}$ direct repeats as in plasmid pWW0-8 (Fig. 2; Downing et al., 1979); hence PaW174 will not grow on any of the usual substrates of the toluene-xylene pathway, such as $m$-xylene or $m$-toluate, but it will grow on benzoate via the chromosomal $\beta$ ketoadipate pathway. In addition it carries an insertion of Tn 401 which confers resistance to carbenicillin. We grew three independent cultures of PaW174 for six cycles through BMM, pH $7 \cdot 0$, and were unable to detect a single colony, out of 528 examined, which had lost the plasmid and hence was $\mathrm{Cb}^{\mathrm{s}}$.

We repeated the experiments with $\mathrm{PaW} 1$ at initial $\mathrm{pH} 7.0$ and 6.4 but growing the cells on minimal medium containing a preferred growth substrate ( $15 \mathrm{mM}$-succinate) in the presence of 5 mM-benzoate. Although we used high-phosphate medium, the $\mathrm{pH}$ in these experiments did change more than when benzoate alone was used (from 7.0 to about 7.3-7.45 and from 6.4 to 7.07.2) but still encompassed the same $\mathrm{pH}$ range as in the experiments with benzoate alone. After three cycles (Table 2) $98-100 \%$ of the colonies examined were wild-type $\left(\mathrm{Mtol}^{+}\right)$, in stark contrast to the experiments with benzoate alone (Table 2). In these experiments we also measured the UV absorption spectra of the media after each growth cycle and generally less than $20 \%$ of the benzoate appeared to have been utilized. It follows that the presence of benzoate is insufficient to cause curing unless it is the major growth substrate. The final experiment in this series was to grow PaWl on another weak organic acid (5 mM-propionate) through three subcultures: in four independent experiments, two at $\mathrm{pH} 7.0$ and two at $\mathrm{pH} 6.4$, we detected only two $\mathrm{Mtol}^{-}$colonies in the 88 examined from each experiment. It is clear from these growth experiments that $\mathrm{pH}$, either directly or indirectly, by changing the degree of ionization of the organic acid growth substrate, has no effect, nor does growth on weak organic acids other than benzoate.

It is impossible to distinguish the phenotypes of the plasmid-free and the deletion mutants of $\mathrm{PaW} 1$ which occur during growth on BMM since they are both $\mathrm{Mtol}^{-} \mathrm{Ben}^{+}$and they do not turn yellow when sprayed with catechol. They could be distinguished by the presence or absence of plasmid DNA, but demonstrating this is time-consuming and has only been done once on a very limited number of strains (Bayley et al., 1977). However, deletion and plasmid loss can be distinguished if derivatives of pWW0 are used which carry a genetic marker such as a transposon inserted in the plasmid outside the $39 \mathrm{kbp}$ region lost in the deletion event. PaW 163 

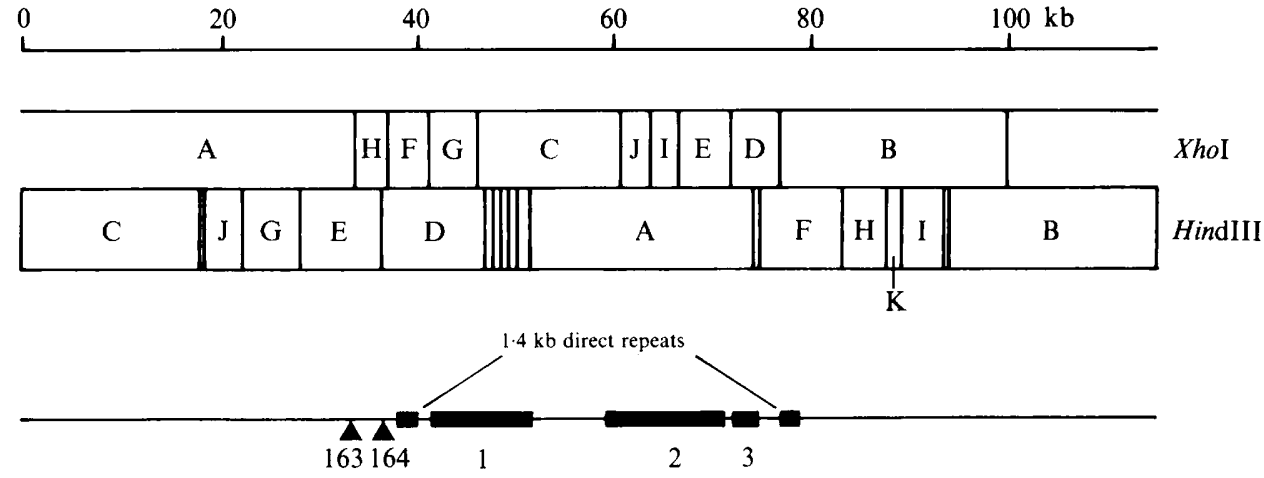

Fig. 2. Linear restriction map of pWW0. The sites for restriction enzymes HindIII and XhoI are shown together and the main fragments are lettered according to Downing \& Broda (1978). The location of the Tn401 insertions in pWW0-163 and pWW0-164 are indicated on the map of the gene organization together with the two $1.4 \mathrm{kbp}$ direct repeats at the termini of the $39 \mathrm{kbp}$ region deleted, the $x y l C A B$ operon (1), the $x y l D L E G F(J K) I H$ operon (2) and the $x y l S R$ regulatory gene region (3).

Table 2. Segregation of $\mathrm{Mtol}^{-}$strains from $\mathrm{PaWl}$ grown on various media

\begin{tabular}{|c|c|c|c|c|c|}
\hline \multirow{3}{*}{ Medium } & \multirow{3}{*}{ Initial $\mathrm{pH}$} & \multicolumn{4}{|c|}{ Percentage of $\mathrm{Mtol}^{+}$cells after } \\
\hline & & \multicolumn{4}{|c|}{ Subcultures: } \\
\hline & & 1 & 2 & 3 & 4 \\
\hline \multirow[t]{8}{*}{5 mM-benzoate (low phosphate) } & $7 \cdot 2$ & $>99$ & 54 & 4 & ND \\
\hline & $7 \cdot 0$ & 98 & 19 & 2 & ND \\
\hline & $7 \cdot 0$ & 97 & 51 & 5 & ND \\
\hline & $7 \cdot 0$ & 98 & 34 & 2 & ND \\
\hline & $6 \cdot 8$ & 96 & 68 & 17 & ND \\
\hline & $6 \cdot 6$ & 87 & 9 & 4 & ND \\
\hline & $6 \cdot 4$ & $>99$ & $>99$ & $>99$ & 92 \\
\hline & $6 \cdot 4$ & 81 & 12 & 2 & ND \\
\hline \multirow[t]{4}{*}{5 mM-benzoate (high phosphate) } & $7 \cdot 0$ & $>99$ & 73 & 9 & 1 \\
\hline & $7 \cdot 0$ & $>99$ & 94 & 44 & $<1$ \\
\hline & $6 \cdot 4$ & 92 & 10 & 2 & ND \\
\hline & $6 \cdot 4$ & $>99$ & 74 & 5 & ND \\
\hline \multicolumn{6}{|l|}{$15 \mathrm{~mm}$-succinate $+5 \mathrm{~mm}$-benzoate } \\
\hline (high phosphate) & $7 \cdot 0$ & ND & ND & 98 & ND \\
\hline & $7 \cdot 0$ & ND & ND & $>99$ & ND \\
\hline & 6.4 & ND & ND & 99 & ND \\
\hline & $6 \cdot 4$ & ND & ND & $>99$ & ND \\
\hline
\end{tabular}

ND, Not determined.

and $\mathrm{PaW} 164$ are hosts to two such plasmids, which have inserts of Tn 401 carrying a $\beta$-lactamase gene conferring $\mathrm{Cb}^{r}$. In pWW0-163 the insert is in the region common to fragments HindIII-E and $X h o-\mathrm{H}$ and in pWW0-164 it is in fragments HindIII-D and Xho-F (Fig. 2; Downing \& Broda, 1978). Deletion of the $39 \mathrm{kbp}$ region produces strains which retain the transposon and are $\mathrm{Mtol}^{-} \mathrm{Ben}{ }^{+} \mathrm{Cb}^{\mathrm{r}}$, whereas plasmid loss results in $\mathrm{Mtol}^{-} \mathrm{Ben}^{+} \mathrm{Cb}^{\mathrm{s}}$ strains. The presence of the Tn 401 on an otherwise cryptic plasmid in the putative deletion strains can be further confirmed by showing that the resistance can be transferred from them by conjugation.

$\mathrm{PaW} 163$ and PaW164 were each grown through three cycles in BMM, pH 7.0, in several independent experiments. Phenotypic analysis of the resulting cultures (Table 3 ) showed that in eight of the 11 experiments only deletion mutants were found and in two the deletion mutants were predominant: in only one case did plasmid-free segregants predominate, and in this 


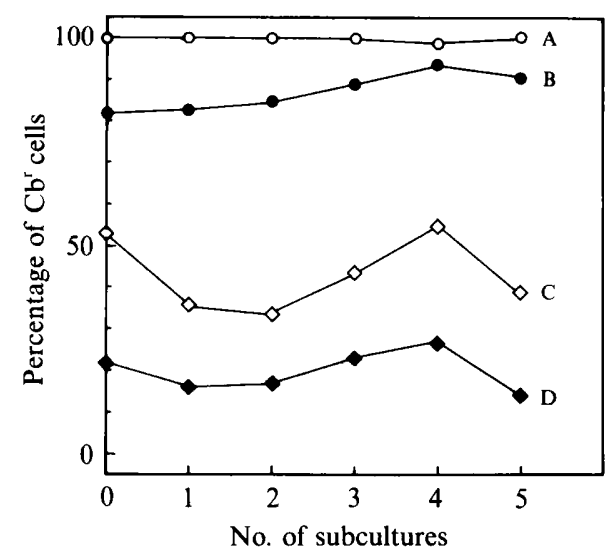

Fig. 3. Competition between PaW8 $\left(\mathrm{Mtol}^{-} \mathrm{Cb}^{\mathrm{s}}\right)$ and $\mathrm{PaWl} 14\left(\mathrm{Mtol}^{-} \mathrm{Cb}^{r}\right)$ growing on benzoate at $\mathrm{pH}$ 7.0: the results are presented as the percentage of $\mathrm{Cb}^{r}$ cells in the population. The cell densities (cells $\mathrm{ml}^{-1}$ ) at the start of the first subculture were: experiment A, PaW174 150, no PaW8 cells added; experiment B, PaW174 600, PaW8 130 (ratio 4.5:1); experiment C, PaW174 150, PaW8 130 (ratio $1 \cdot 2: 1$ ); experiment D, PaW174 40, PaW8 130 (ratio $0 \cdot 3: 1$ ).

Table 3. Effect of growth on benzoate at $p H 7 \cdot 0$ on strains carrying $p W W 0::$ Tn401 plasmids

$\begin{array}{ccccc}\text { Strain } & \begin{array}{c}\text { Experiment } \\ \text { no. }\end{array} & \overbrace{\mathrm{Mtol}^{+} \mathrm{Cb}^{\mathrm{r}}}^{\text {No. of colonies with phenotypes }} & \mathrm{Mtol}^{-} \mathrm{Cb}^{\mathrm{r}} & \mathrm{Mtol}^{-} \mathrm{Cb}^{\mathbf{5}} \\ \text { PaW163 } & 1 & 1 & 87 & 0 \\ & 2 & 17 & 71 & 0 \\ & 3 & 1 & 87 & 0 \\ \text { PaW164 } & 4 & 2 & 74 & 12 \\ & 5 & 0 & 86 & 0 \\ & 1 & 3 & 53 & 88 \\ & 2 & 1 & 63 & 0 \\ & 3 & 3 & 87 & 0 \\ & 4 & 0 & 85 & 0\end{array}$

experiment they were the only type found. As controls we demonstrated that PaW174, a deletion strain derived from $\mathrm{PaW} 164$, stably retained its $\mathrm{Cb}^{r}$ phenotype through five subcultures in $\mathrm{BMM}, \mathrm{pH} 7 \cdot 0$, thus eliminating the possibility that the putative plasmid-free segregants could arise from excision of the transposon from the deleted plasmid (Fig. 3, line A) and also incidentally further confirming that $\mathrm{pWW} 0-174$ is totally stable under growth conditions where pWW0 segregates either deletions or plasmid-free derivatives (Table 2). We also showed that there was no selective advantage in the presence of Tn401 during growth on BMM and that in mixtures of $\mathrm{PaWl} 14$ with $\mathrm{PaW} 8\left(\mathrm{Mtol}^{-} \mathrm{Ben}^{+} \mathrm{Cb}^{\mathrm{s}}\right)$ neither outcompeted the other (Fig. 3, lines B-D).

If it is assumed that the transposon does not influence the mode of segregation, and this assumption can be partly justified since plasmids with insertions in two different locations were used, this experiment (Table 3) indicates that deletion is a more frequent event than is plasmid loss. However, the differences between individual experiments again illustrate the random nature of the events which produce the strains which eventually predominate in the culture. 


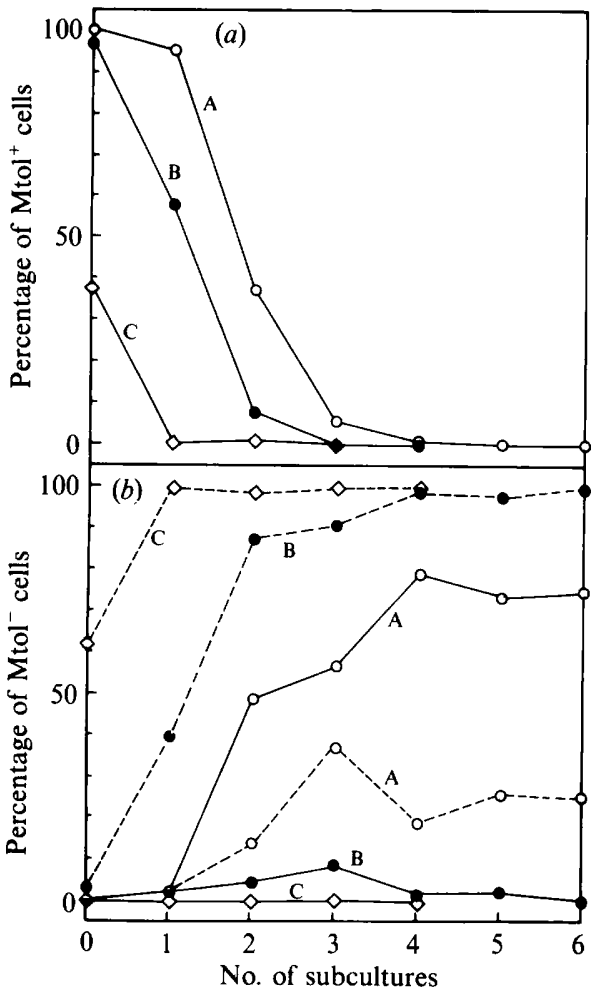

Fig. 4

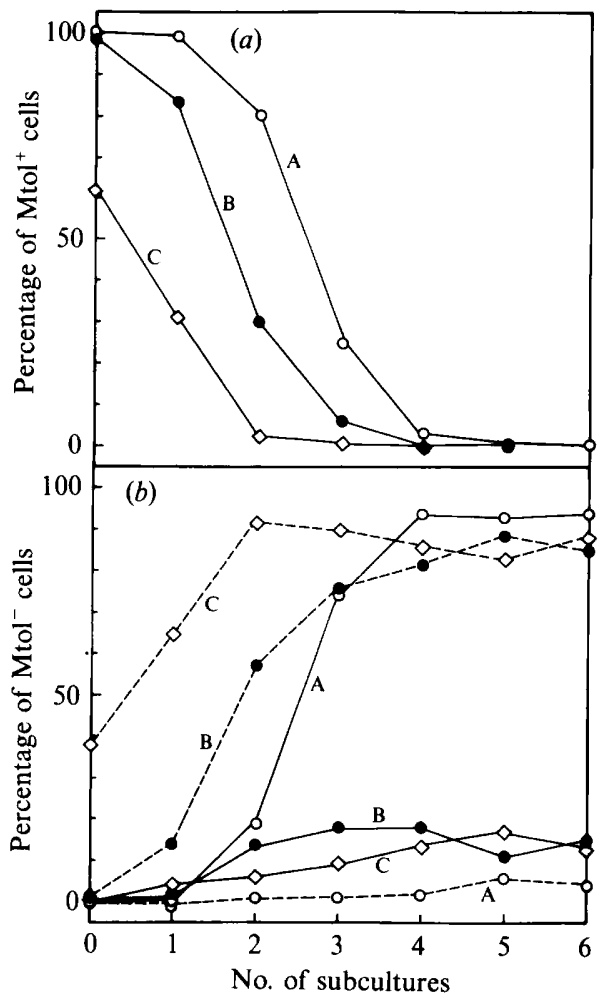

Fig. 5

Fig. 4. Competition between $\mathrm{PaW} 1$ and $\mathrm{PaW} 174$ growing on benzoate at $\mathrm{pH} 7 \cdot 0$. (a) Percentage of wild-type cells $\left(\mathrm{Mtol}^{+} \mathrm{Cb}^{\mathrm{s}}\right)$. (b) Percentage of 'cured' strains (---) with phenotypes $\mathrm{Mtol}^{-} \mathrm{Cb}^{\mathrm{r}}$ (PaW174) and (-) with phenotypes $\mathrm{Mtol}^{-} \mathrm{Cb}^{\mathrm{s}}$ (segregants of PaW1). The cell densities (cells $\mathrm{ml}^{-1}$ ) at the start of the first subculture were: experiment A, PaW1 1.7 $\times 10^{5}, \mathrm{PaW} 174270$ (ratio 630:1); experiment B, PaW1 $8.5 \times 10^{3}$, PaW1 14270 (ratio $30: 1$ ); experiment C, PaW1 170, PaW174 270 (ratio $0 \cdot 6: 1)$.

Fig. 5. Competition between $\mathrm{PaW} 1$ and $\mathrm{PaW} 174$ growing on benzoate at pH 6.4. (a) Percentage of wild-type cells $\left(\mathrm{Mtol}^{+} \mathrm{Cb}^{\mathrm{s}}\right)$. (b) Percentage of 'cured' strains (-.-) with phenotypes $\mathrm{Mtol}^{-} \mathrm{Cb}^{\mathrm{r}}$ (PaW 174) and ( - ) with phenotypes $\mathrm{Mtol}^{-} \mathrm{Cb}^{\mathrm{s}}$ (segregants of $\mathrm{PaW1}$ ). The cell densities (cells $\mathrm{ml}^{-1}$ ) at the start of the first subculture were: experiment A, PaW1 1.3 $\times 10^{5}$, PaW174 80 (ratio 1600:1); experiment B, PaW1 $6.8 \times 10^{3}$, PaW174 80 (ratio 85: 1); experiment C, PaW1 130, PaW174 80 (ratio $1 \cdot 6: 1)$.

\section{Competition experiments}

Because of the stable retention of pWW0-174 during growth on benzoate we set up competition experiments at $\mathrm{pH} 7.0$ and $\mathrm{pH} 6.4$ in which mixtures of $\mathrm{PaWl}$ and $\mathrm{PaW} 174$ were inoculated into BMM in different initial cell ratios, and the composition of the culture was monitored during successive subcultures. This enabled determination of the individual growth advantages of the two strains and simultaneously it was possible to distinguish between the 'cured' strain seeded into the culture (PaW174) and any spontaneous 'cured' derivatives of $\mathrm{PaW} 1$ which arose during the course of the experiment. The results at $\mathrm{pH} 7.0$ are shown in Fig. 4. As was expected from the results of the earlier experiments, the wild-type was lost from the culture even when present initially in a 630:1 preponderance over PaW174 (Fig. $4 a$, line A). When PaW 174 was present at about $60 \%$ of the initial population (Fig. $4 \mathrm{~b}$, lines C) or at about $3 \%$ (Fig. $4 b$, lines B), it ultimately took over as the dominant strain $(>95 \%)$, but when it was initially present as only about $1 \%$ (Fig. $4 b$, lines A), the final culture contained a higher proportion of $\mathrm{Mtol}^{-} \mathrm{Ben}^{+} \mathrm{Cb}^{\mathrm{s}}$ strains, which must have arisen from $\mathrm{PaW} 1$ either by deletion 
(probably) or by plasmid loss (possibly). The control experiment in which PaW174 was competed with PaW8, a 'cured' strain but with a deleted plasmid pWW0-8 (Bayley et al., 1977; Downing et al., 1979), is shown in Fig. 3; neither strain has a selective growth advantage on BMM, pH 7.0.

Qualitatively similar results were found when the experiment was repeated at $\mathrm{pH} 6.4$ (Fig. 5), when $\mathrm{Mtol}^{-} \mathrm{Ben}^{+} \mathrm{Cb}^{\mathrm{s}}$ strains ultimately predominated when the initial ratio of $\mathrm{PaW} 1: \mathrm{PaW} 174$ was about 1600 (Fig. $5 b$, lines A) but at lower ratios PaW174 became predominant.

The result showing that $\mathrm{PaW} 174$ takes over the population when initially present even as a minority component, resulting in loss of wild-type $\mathrm{PaW} 1$ from the population at a comparable rate to that seen when $\mathrm{PaW} 1$ is grown on $\mathrm{BMM}$ alone (compare Table 2 with Figs 4 and 5), must lead to the conclusion that the normal 'benzoate curing' of PaW1 (Table 2) can be explained by the simple selection on benzoate of faster-growing strains. Additionally the data of Figs 4 and 5 allow a rough estimate of the frequency of spontaneous occurrence within populations of $\mathrm{PaW} 1$ of the strains which give rise to the 'curing'. The implication of the data is that such strains are present at the surprisingly high frequency of $10^{-2}-10^{-3}$, so that when the culture is inoculated with another 'cured' strain (as PaW174) at cell ratios below this, the spontaneously formed strains ultimately predominate, whereas when the seeded strain is added at higher ratios than $10^{-2}$, it will ultimately take over.

\section{DISCUSSION}

The results presented here show conclusively that the progressive takeover of populations of PaWl by segregants which have lost the meta pathway genes either by deletion or by plasmid loss can be adequately explained by their faster rate of growth under the experimental conditions, batch culture on BMM, which have routinely been used by us and others in studies of TOL plasmids (Williams \& Worsey, 1976; Worsey \& Williams, 1977; Kunz \& Chapman, 1981; Pickup \& Williams, 1982; Pickup et al., 1983; Keil \& Williams, 1985).

There is no evidence with these studies that the segregation of the $\mathrm{Mtol}^{-}$strains is due to a direct effect of benzoate or other anions as proposed by Stephens \& Dalton (1987). (1) There is no effect of lowering the $\mathrm{pH}$ from 7.0 to 6.4 on the efficacy of 'curing'. (2) Growth of PaW1 on 5 mM-propionate at $\mathrm{pH} 7.0$ and $\mathrm{pH} 6.4$ does not cause any segregation of $\mathrm{Mtol}^{-}$strains. (3) Growth of PaW174 on benzoate causes no loss of its plasmid pWW0-174: since this plasmid contains the complete replicon of pWW 0 and lacks only the $39 \mathrm{kbp}$ region, whose only known role is to encode the catabolic genes, any direct effect of benzoate on plasmid segregation should cause loss similar to that found with $\mathrm{pWW} 0$ itself.

We have shown that the loss of the $\mathrm{Mtol}^{+}$phenotype only occurs when there is the selective advantage of growth on benzoate available for the segregants: when cells are grown on media where there is an alternative carbon source which requires only constitutive enzymes, such as $15 \mathrm{~mm}$-succinate, even when $5 \mathrm{~mm}$-benzoate is present, no segregation takes place.

Strain PaW701, a $P$. putida $\mathrm{mt}-2$ host carrying the naphthalene catabolic plasmid pWW60-1, does not segregate any mutants of the plasmid-coded pathway after growth on benzoate. This confirms both of the arguments of the preceding paragraphs. Firstly pWW60-1 is of the same incompatibility group, IncP9, as $\mathrm{pWW} 0$ and therefore presumably shares similar, if not identical, replication and partition mechanisms: any effect of benzoate on plasmid replication and partition would be expected to act equally against this very similar plasmid as against pWW 0 . The lack of any such mutants after growth on benzoate therefore suggests that there is no such effect and at the same time reinforces our argument about selection. In the case of TOL plasmids, benzoate can be utilized either by the plasmid pathway or by the chromosomal pathway but, because of the regulatory differences between the two routes, only the plasmid pathway is expressed in the $\mathrm{TOL}^{+}$wild-types: only by loss or mutational malfunction of the plasmid pathway can the chromosomal route be used and, as is proposed here, such strains will outcompete the wild-type because of their faster growth rate. However, no such selection can occur in the case of PaW701 since benzoate is not a substrate of the naphthalene-plasmiddetermined pathway and therefore it is catabolized by the chromosomal pathway whether 
plasmid is present, absent or mutated. Thus $\mathrm{Nah}^{-}$mutants would not be expected on the growthrate hypothesis but would be if benzoate caused plasmid loss or deletion. The fact that Clarke \& Laverack (1984) reported a high frequency of loss of naphthalene and TOL plasmids (including pWW0) is not relevant to this argument since their protocol involved plating strains on to very high concentrations of benzoate (20-50 mM), just below growth-inhibitory levels where undoubtedly other factors operate.

The growth-rate hypothesis is confirmed by our competition experiments where cultures of $\mathrm{PaW} 1$ were inoculated at various dilutions with $\mathrm{PaW} 174$, carrying a transposon-marked plasmid. At initial cell concentrations of about $1 \%$ of the wild-type, PaW 174 becomes the predominant strain after 60-80 generations and the curves follow the theoretical curves for growth-rate-determined competition (Stephens \& Dalton, 1987). At lower initial cell ratio, although $\mathrm{PaW} 174$ is still present as a significant component of the population after 100 generations, 'cured' derivatives of $\mathrm{PaWl}$ predominate and this suggests that their presence within unselected populations of $\mathrm{PaWl}$ is between $10^{-2}$ and $10^{-3}$ : this is an order of magnitude higher than the value of about $4 \times 10^{-4}$ estimated by Nakazawa \& Yokota (1973) from fluctuation analysis with their clone of strain mt-2.

This paper also demonstrates for the first time that plasmid deletion appears to occur more frequently than does plasmid loss in these experiments. This is perhaps not surprising since pWW0 contains two direct repeats of $1.4 \mathrm{kbp}$ (Meulien et al., 1981) at either end of the $39 \mathrm{kbp}$ region deleted (Fig. 2), which would serve as regions upon which the Rec system might act. A testable consequence of this might be that benzoate selection should be far less effective in a $\mathrm{Rec}^{-}$host. We have evidence that some of the strains which are hosts to other different TOL plasmids which undergo loss of wild-type during growth on benzoate, including P.putida MT15 used by Stephens \& Dalton (1987), have even larger regions of DNA homology within the plasmid due to extensive duplications of catabolic genes. These might also serve as templates for Rec-dependent deletion events (Chatfield \& Williams, 1986; Keil et al., 1987; K. J. O'Donnell \& P. A. Williams, unpublished results) causing loss or malfunction of expression of the toluenexylene catabolic genes and giving rise to host cells which use the chromosomal pathway and which are then positively selected during subsequent growth on benzoate because of their faster growth rate.

\section{REFERENCES}

Bauchop, T. \& ElsDen, S. R. (1960). The growth of micro-organisms in relation to their energy supply. Journal of General Microbiology 23, 457-469.

Bayley, S. A., Duggleby, C. J., Worsey, M. J., Williams, P. A., Hardy, K. G. \& Broda, P. (1977). Two modes of loss of the Tol function from Pseudomonas putida mt-2. Molecular and General Genetics 154, 203-204.

Cane, P. A. \& Williams, P. A. (1982). The plasmidcoded metabolism of naphthalene and 2-methylnaphthalene in Pseudomonas strains: phenotypic changes correlated with structural modification of the plasmid pWW60-1. Journal of General Microbiology 128, 2281-2290.

Chatfield, L. K. \& Williams, P. A. (1986). Naturally occurring TOL plasmids in Pseudomonas strains carry either two homologous or two nonhomologous catechol 2,3-oxygenase genes. Journal of Bacteriology 168, 878-885.

Clarke, P. H. \& Laverack, P. D. (1984). Growth characteristics of Pseudomonas strains carrying catabolic plasmids and their cured derivatives. FEMS Microbiology Letters 24, 109-112.

Downing, R. G. \& BrodA, P. (1978). A cleavage map of the TOL plasmid of Pseudomonas putida mt-2. Molecular and General Genetics 168, 189-191.
Downing, R. G., Duggleby, C. J., Villems, R. \& BRODA, P. (1979). An endonuclease map of the plasmid pWW0-8, a derivative of the TOL plasmid of Pseudomonas putida mt-2. Molecular and General Genetics 177, 97-99.

Franklin, F. C. H., Bagdasarian, M., Bagdasarian M. M. \& Timmis, K. N. (1981). Molecular and functional analysis of the TOL plasmid $\mathrm{pWW} 0$ from Pseudomonas putida and cloning of the entire regulated aromatic ring meta cleavage pathway. Proceedings of the National Academy of Sciences of the United States of America 78, 7458-7462.

KeIL, H. \& Williams, P. A. (1985). A new class of TOL plasmid deletion mutants in Pseudomonas putida MT15 and their reversion by tandem gene amplification. Journal of General Microbiology 131, 1023-1033.

KeIL, H., KeIL, S. \& Williams, P. A. (1987). Molecular analysis of regulatory and structural $x y l$ genes of the TOL plasmid pWW53-4. Journal of General Microbiology 133, 1149-1158.

Keshavarz, T., Lilly, M. D. \& Clarke, P. H. (1985). Stability of a catabolic plasmid in continuous culture. Journal of General Microbiology 131, 11931203.

KunZ, D. A. \& Chapman, P. J. (1981). Isolation and characterization of spontaneously occurring TOL 
plasmid mutants of Pseudomonas putida HS1. Journal of Bacteriology 146, 952-962.

LeHRBACH, P. R. \& Timmis, K. N. (1983). Genetic analysis and manipulation of catabolic pathways in Pseudomonas. Biochemical Society Symposia 48, 191291.

Meulien, P., Downing, R. G. \& BRoda, P. (1981). Excision of the $40 \mathrm{~kb}$ segment of the TOL plasmid from Pseudomonas putida mt-2 involves direct repeats. Molecular and General Genetics 184, 97-101.

NaKaZawa, T. \& Yokota, T. (1973). Benzoate metabolism in Pseudomonas putida (arvilla) $\mathrm{mt}-2$ : demonstration of two benzoate pathways. Journal of Bacteriology 115, 262-275.

Pickup, R. W. \& Williams, P. A. (1982). Spontaneous deletions in the TOL plasmid pWW20 which give rise to the $\mathrm{B} 3$ regulatory mutants of Pseudomonas putida MT20. Journal of General Microbiology 128, $1385-1390$

Pickup, R. W., Lewis, R. J. \& Williams, P. A. (1983). Pseudomonas sp. MT14, a soil isolate which contains two large catabolic plasmids, one a TOL plasmid and one coding for phenylacetate catabolism and mercury resistance. Journal of General Microbiology 129, 153-158.

Stephens, G. M. \& Dalton, H. (1987). The effect of lipophilic weak acids on the segregational stability of TOL plasmids in Pseudomonas putida. Journal of General Microbiology 133, 1891-1899.

WheATCRoft, R. \& Williams, P. A. (1981). Rapid methods for the study of both stable and unstable plasmids in Pseudomonas. Journal of General Microbiology 124, 433-437.

Williams, P. A. \& Murray, K. (1974). Metabolism of benzoate and the methylbenzoates by Pseudomonas putida (arvilla) mt-2: evidence for the existence of a TOL plasmid. Journal of Bacteriology 120, 416-423. WILliaMS, P. A. \& WORSEY, M. J. (1976). Ubiquity of plasmids in coding for toluene and xylene metabolism in soil bacteria: evidence for the existence of new TOL plasmids. Journal of Bacteriology 125, 818-828.

Worsey, M. J. \& Williams, P. A. (1975). Metabolism of toluene and xylenes by Pseudomonas putida (arvilla) $\mathrm{mt}-2$ : evidence for a new function of the TOL plasmid. Journal of Bacteriology 124, 7-13.

Worsey, M. J. \& Williams, P. A. (1977). Characterization of a spontaneously occurring mutant of the TOL20 plasmid in Pseudomonas putida MT20: possible regulatory implications. Journal of Bacteriology 130, 1149-1158. 